\title{
Abnormalities of autonomic function in the Lambert Eaton myasthenic syndrome
}

\author{
J P HEATH,* D J EWING, R E CULL \\ From the Department of Neurology and University Department of Medicine, Royal Infirmary, Edinburgh, UK
}

SUMMARY Two cases of Lambert Eaton syndrome unassociated with an underlying malignancy are described. Both had mild autonomic symptoms but markedly abnormal autonomic function tests. These results are suggestive of a widespread defect in cholinergic transmission in addition to that at the skeletal neuromuscular junction.

The Lambert Eaton myasthenic syndrome (LEMS) comprises proximal limb weakness and fatiguability associated with a characteristic incrementing electromyographic response to stimulus rates above $10 \mathrm{~Hz}{ }^{1}$ Most frequently it is encountered in association with carcinoma (Ca-LEMS) particularly oat cell tumours of the lung in which it has a prevalence of $3 \% .^{2}$ Cases have also been reported in association with lymphosarcoma ${ }^{1}$ carcinoma of the breast, colon, stomach and prostate, ${ }^{3}$ bladder, ${ }^{4}$ kidney and gall bladder. ${ }^{5}$ Approximately one third of cases are not associated with malignant disease (non Ca-LEMS). ${ }^{6}$ The underlying physiological abnormality lies in the presynaptic membrane where there is a decrease in the number of quanta of acetylcholine released by each nerve impulse although the resting frequency of miniature end plate potentials and quantal size are unaltered.7,8

Symptoms possibly related to autonomic involvement occur in about half the patients and are usually confined to a dry mouth and, in men, impotence ${ }^{9}$ although impaired sweating ${ }^{10}$ and constipation ${ }^{11}$ have also been reported. Autonomic function tests have been formally assessed previously in four LEMS patients. ${ }^{10,12,13}$ Two groups of workers ${ }^{1213}$ found

Address for correspondence: Dr D J Ewing, Department of Medicine, Royal Infirmary, Edinburgh EH3 9YW, UK.

Received 24 April 1987 and in revised form 29 October 1987. Accepted 2 November 1987

Reprints will not be available from the authors.

*Present address: the Department of Clinical Neurophysiology, Leeds General Infirmary, Leeds, UK. evidence of both sympathetic and parasympathetic dysfunction and have inferred the involvement of adrenergic synapses while the other group observed abnormalities confined to the parasympathetice system. ${ }^{10}$ We describe two further patients with minimal autonomic symptoms but extensive abnormalities of autonomic function.

\section{Case reports}

Case 1

A 59 year old man presented in 1978 with a 2 year history of proximal arm weakness and 1 year of difficulty in walking, mild bilateral ptosis, intermittent diplopia on upward gaze worse in the evening, difficulty in swallowing food, and weakness of his voice. He had a solitary generalised seizure in 1965 and had been taking phenobarbitone $90 \mathrm{mg} /$ day ever since. There was no family history of neurological disease but his mother suffered from thyroid disease. He had never smoked. On examination he had vitiligo over the face and arms, bilateral ptosis but normal eye movements. There was no weakness of the arms or legs, tendon reflexes were generally depressed and the plantar responses were flexor. Muscle tone, coordination and sensation were all normal. His ptosis did not response to edrophonium. Repetitive stimulation of the ulnar nerve revealed an early decrement in the amplitude of the abductor digiti minimi compound action potential at $2 \mathrm{~Hz}$ but an increment of $200 \%$ at $30 \mathrm{~Hz}$ consistent with a diagnosis of LEMS. A search was made for an underlying tumour. Chest radiographs, sputum cytology, blood film and ESR, urea, electrolytes, glucose, protein, electrophoresis, calcium, liver and thyroid function tests, VDRL, isotope scans of the liver and pancreas, barium meal and ultrasound examination of the abdomen were all normal. Autoantibodies were present to gastric parietal cells and thyroid cytoplasm. He was started on guanidine $20 \mathrm{mg}$ per $\mathrm{kg}$ body weight and his symptoms improved. He has been 
under regular review since 1978 and has shown no evidence of underlying tumour. He has had three further generalised seizures and his anticonvulsant was changed to phenytoin; the electroencephalogram and CT brain scan were normal. In 1984 routine haematological screening revealed a haemoglobin of $13.1 \mathrm{~g} / \mathrm{dl}$ and an MCV of $102 \mathrm{fl}$. Serum $B_{12}$ was low at $134 \mathrm{ng} / \mathrm{l}$; on Schilling testing he excreted $3.6 \%$ of the $\mathrm{B}_{12}$ dose (normal $>7 \cdot 5 \%$ ). He has subsequently received regular $B_{12}$ injections. His only possible autonomic symptom has been a dry mouth. He had no postural hypotension, impotence, visual, sphincter or sweating disturbances.

\section{Case 2}

A 72 year old man presented in December, 1986 with a right lower lobe pneumonia which resolved rapidly with antibiotic therapy. He had a 12 year history of difficulty in walking. After 100 yards his legs became tired, his knees gave way and his feet became floppy. He had noticed no arm, facial or bulbar weakness or other neurological symptoms. His only past illness was a benign prostatic hypertrophy for which he underwent surgery in 1985 . There was no family history of neurological or autoimmune disease. He had smoked a pipe up to 1971 but never cigarettes. On examination he had slight weakness of both quadriceps muscles. Tone, coordination and sensation were normal. At rest all the tendon reflexes were absent, even with reinforcement, but after forceful contraction of the relevant muscle for 15 seconds they recovered transiently. The plantar responses were flexor and the cranial nerves intact. Sensory and motor nerve conduction velocities and sensory nerve amplitudes were normal. Muscle compound action potentials were reduced in amplitude but showed an incrementing response to repetitive stimulation at rates above $10 \mathrm{~Hz}$ (fig) confirming the diagnosis of LEMS. On recovery from his pneumonia the chest radiograph was normal and bronchoscopy, including cytological examination of bronchial washings, showed no evidence of malignancy. Haemoglobin, blood film, serum $B_{12}$ and folate, electrolytes, blood glucose, serum calcium, liver and thyroid function tests, VDRL, antinuclear factor, thyroid and parietal cell antibodies were all normal. Protein electrophoresis showed a diffuse increase in alpha 1 and 2 and gamma globulin fractions. He was started on guanidine $10 \mathrm{mg}$ per $\mathrm{kg}$ and was subsequently able to walk 2 miles without resting. His only symptom suggestive of autonomic dysfunction was a dry mouth. He had always been prone to constipation but this had not increased in severity with

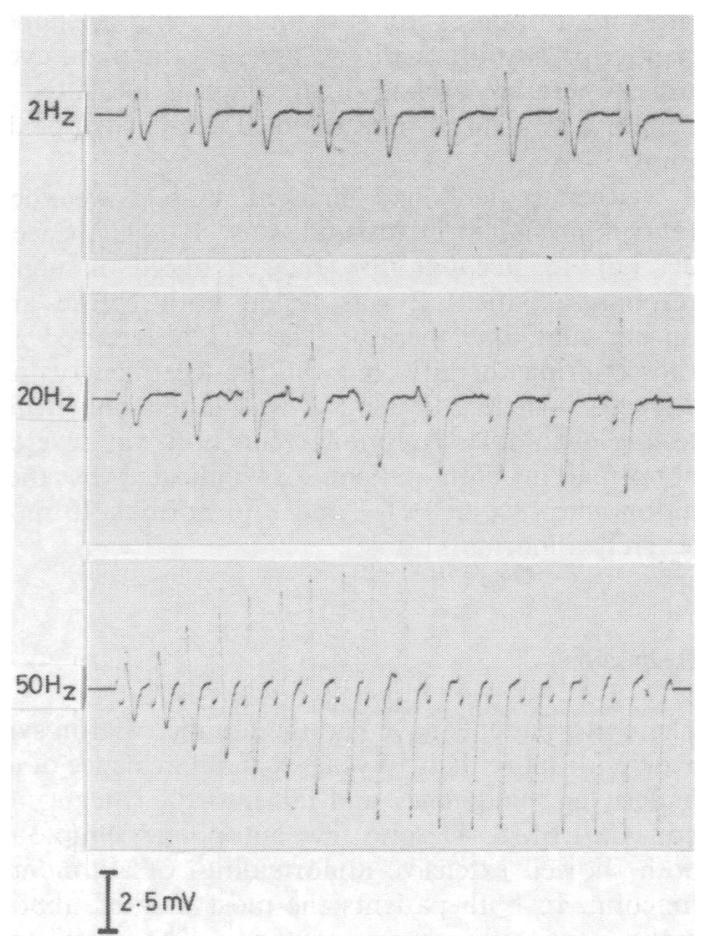

Fig The muscle action potentials recorded from the surface of abductor digiti minimi following electrical stimulation of the ulnar nerve at the wrist at different frequencies.

his gait disturbance. He had no impotence, abnormalities of sweating, symptoms of postural hypotension or visual difficulties.

\section{Methods and Results}

Both patients were investigated using a battery of non-invasive autonomic function tests which we have described in detail previously. ${ }^{14,15}$ These comprised the heart rate responses to the Valsalva manoeuvre, standing up and deep breathing, and the blood

Table Individual autonomic function test results

\begin{tabular}{|c|c|c|c|c|c|c|c|}
\hline & \multicolumn{3}{|c|}{ Heart rate response to } & \multicolumn{4}{|c|}{ Blood pressure response to } \\
\hline & $\begin{array}{l}\text { Valsalva } \\
\text { manoeuvre } \\
\text { (Valsalva } \\
\text { ratio) }\end{array}$ & $\begin{array}{l}\text { Standing up } \\
(30: 15 \\
\text { ratio) }\end{array}$ & $\begin{array}{l}\text { Deep } \\
\text { breathing } \\
\text { (max-min } \\
\text { heart rate } \\
\text { beats/min) }\end{array}$ & $\begin{array}{l}\text { Standing up } \\
\text { (Systolic } \\
\text { BP mmHg) }\end{array}$ & $\begin{array}{l}\text { Sustained } \\
\text { handgrip } \\
\text { (Diastolic } \\
\text { BP } \text { mm Hg) }\end{array}$ & $\begin{array}{l}\text { Autonomic* } \\
\text { Score } \\
(0-10)\end{array}$ & $\begin{array}{l}\text { Pupil cycle } \\
\text { time (ms) }\end{array}$ \\
\hline $\begin{array}{l}\text { Patient } \\
\text { Case } 1 \\
\text { Case } 2 \\
\text { Normal values }\end{array}$ & $\begin{array}{r}1.05 \\
1.04 \\
\geqslant 1.21\end{array}$ & $\begin{array}{r}1.02 \\
1.00 \\
\geqslant 1.04\end{array}$ & $\begin{array}{r}3 \\
5 \\
\geqslant 15\end{array}$ & $\begin{array}{c}+2 \\
-12 \\
\leqslant-10\end{array}$ & $\begin{array}{r}8 \\
14 \\
\geqslant 16\end{array}$ & $\begin{array}{l}7 \\
8\end{array}$ & $\begin{array}{l}\mathrm{R} \quad \mathrm{L} \\
\text { No response } \\
1190 \quad 1210 \\
\quad<1150\end{array}$ \\
\hline
\end{tabular}

*[Autonomic score is derived by grading the tests as normat (0), borderline (1) or abnormal (2), giving a possible score of 0 - 10 for the five tests.] 
pressure responses to standing up and sustained handgrip. ${ }^{14}$ Additionally we assessed the pupil cycle time, where the cycling of the pupil is measured in response to a slit of light directed at the edge of the pupil. ${ }^{15}$

Neither patient had marked muscle weakness (maximum handgrip strength: Case $1,34 \mathrm{~kg}$, Case 2 $30 \mathrm{~kg}$ ) to account for their reduced handgrip responses. Patient 2 was tested both before and during guanidine therapy. The results reported are those during therapy, but the pre-treatment values were very similar. Patient 1 was tested only while taking guanidine. Autonomic function was severely abnormal in both patients, as indicated by their autonomic "scores" of 7 and 8 (0 normal, 10 most severely abnormal) (table).

\section{Discussion}

These two patients have had the Lambert Eaton syndrome for more than 10 years without evidence of an underlying malignancy and fall into the category of non Ca-LEMS. Despite few autonomic symptoms both showed extensive abnormalities of autonomic function. In both patients the most marked abnormalities were of heart rate responses. These tests predominantly reflect cardiac parasympathetic integrity and our findings agree with those of Rubenstein et $a l^{10}$ who showed parasympathetic dysfunction but no postural hypotension in a 47 year old woman with non Ca-LEMS. By contrast, Mamdani et al $^{12}$ and Khurana et al ${ }^{13}$ described three patients with marked postural hypotension and increased sensitivity to infused sympathetic agonists. As two of their patients had underlying oat cell carcinomas and the other only a short history it is probable that their apparent sympathetic involvement may have been due either to an associated paraneoplastic autonomic neuropathy ${ }^{16}$ or to the impairment of cardiovascular reflexes, sometimes found in patients with bronchial carcinoma without other evidence of autonomic dysfunction. ${ }^{17}$ We did not infuse sympathomimetics in our subjects. This test is not without risk and the results can be difficult to interpret particularly in LEMS where there is no evidence of axonal loss and the post synaptic membrane appears to be normal. ${ }^{7-9}$

Mamdani et al $^{13}$ suggested that the improvement in both autonomic and skeletal muscle function following treatment was due to the removal of a neurohumoral factor secreted by the tumour. However, it is more likely that LEMS is due to a circulating autoantibody as IgG taken from the plasma of patients transfers the disease to mice ${ }^{18}$ whereas transplanting small cell tumours from LEMS patients into mice does not. ${ }^{19}$ Furthermore, there is an increased inci- dence of other autoimmune diseases in LEMS but particularly in non Ca-LEMS where organ specific autoantibodies are present in about half ${ }^{20}$ and plasma exchange results in an improvement in the amplitude of the compound muscle action potential. $^{21}$ There is also a significant association with the HLA type B8 particularly in non Ca-LEMS. ${ }^{22}$

The mechanism by which the antibody interferes with synaptic transmission is not known. Roberts et $a l^{23}$ have suggested that antibody production may be triggered by calcium channel determinants as the potassium induced calcium flux into cultured small cell carcinoma cells is inhibited by LEMS IgG. The antigens provoking LEMS IgG production in patients without carcinoma have not been identified.

The abnormalities of autonomic function in our patients suggest that transmission at cholinergic autonomic synapses is also affected in LEMS. While it is possible to explain the abnormalities in heart rate on the basis of defective transmission at post-ganglionic parasympathetic synapses, both patients also showed an impaired rise in diastolic blood pressure following sustained handgrip. This suggests that pre-ganglionic sympathetic synapses may be involved, or alternatively that adrenergic transmission is affected in LEMS as suggested by Mamdani ${ }^{13}$ and Khurana. ${ }^{2}{ }_{\mathbb{D}}$ We do not feel that it is possible to distinguish between these possibilities on the basis of in vivoo physiological responses.

We thank Dr A C Douglas for allowing us to report his patient. Dr D J Ewing is a Wellcome Trust Senior Lecturer.

\section{References}

1 Eaton LM, Lambert EH. Electromyography and electric stimulation of nerves in diseases of the motor unit. Observations on myasthenic syndrome associated with malignant tumours. JAMA 1957;163:1117-24.

2 Hawley RJ, Cohen MH, Saini N, Armbrustmacher VW. The carcinomatous neuromyopathy of oat cell lung cancer. Ann Neurol 1980;7:65-72.

3 Adams RD. Diseases of Muscle. A Study in Pathology. 3rd ed, Maryland: Harper Row, Hagerstown, 1975.

4 Lambert EH. Defects of neuromuscular transmission in syndromes other than myasthenia gravis. Ann $N$ Y Acad Sci 1955;135:367-84.

5 Lundh H, Nilsson O, Rosen I. Treatment of Lambert Eaton syndrome: 3, 4 diaminpyridine and pyridostigmine. Neurology 1984;34:1324-30.

6 Newsom-Davis J. Diseases of the neuromuscular junction. In: Asbury AK, McKhann GM, McDonald WI, eds. Diseases of the Nervous System. Clinical Neurobiology. Philadelphia: Saunders Co, 1986;269-82.

7 Elmqvist D, Lambert E. Detailed analysis of neuromuscula transmission in a patient with the myasthenic syndrome associated with bronchogenic carcinoma. Mayo Clin Proc 1968;43:689-713.

8 Lambert E, Elmqvist D. Quantal components of endplate potentials in the myasthenic syndrome. Ann $N$ Y Acad Sci 
1971;183:183-99.

9 Lambert EH, Rooke ED. Myasthenic state and lung cancer. In: Brain L, Norris F, eds. The Remote Effects of Cancer on the Nervous System. Contemporary Neurology Symposia. New York: Grune and Stratton Inc 1965;67-80.

10 Rubenstein AE, Horowitz SH, Bender AN. Cholinergic dysautonomia and Eaton-Lambert syndrome. Neurology 1979;29: $720-3$.

11 Henriksson GK, Nilsson O, Rosen I, Schiller HH. Clinical, neurophysiological and morphological findings in Eaton Lambert syndrome. Acta Neurol Scand 1977;56:117-40.

12 Khurana RK, Koski CL, Mayer RF. Dysautonomia in EatonLambert syndrome. Ann Neurol 1983;14:123.

13 Mamdani MB, Walsh RL, Rubino FA, Brannegan RT, Hwang MH. Autonomic dysfunction and Eaton Lambert syndrome. $J$ Auton Nerv Syst 1985;12:315-20.

14 Ewing DJ. Practical bedside investigation of diabetic autonomic failure. In: Bannister R, ed. Autonomic Failure: a Textbook of Clinical Disorders of the Autonomic Nervous System. Oxford: Oxford University Press, 1983;371-405.

15 Martyn CN, Ewing DJ. Pupil cycle time: a simple way of measuring an autonomic reflex. J Neurol Neurosurg Psychiatry 1986;49:771-4.

16 Ahmad MN, Carpenter S. Autonomic neuropathy and car- cinoma of the lung. Can Med Assoc J 1975;113: 410-2.

17 Gould GA, Ashworth M, Lewis GTR. Are cardiovascular reflexes more commonly impaired in patients with bronchial carcinoma? Thorax 1986;41:372-5.

18 Lang B, Newsom-Davis J, Wray D. Autoimmune aetiology for myasthenic (Eaton-Lambert) syndrome. Lancet 1981;ii:224-6.

19 Lambert EH, Lennon VA. Neuromuscular transmissible in nude mice bearing oat cell tumours from Lambert-Eaton myasthenic syndrome. Muscle Nerve 1982;5:S39-S45.

20 Lennon VA, Lambert EH, Wittingham S, Fairbanks V. Autoimmunity in the Eaton Lambert myasthenic syndrome. Muscle Nerve 1982;5:S21-S25.

21 Newsom-Davis J, Murray NMF. Plasma exchange and immunosuppressive drug treatment in the Lambert Eaton myasthenic syndrome. Neurology 1984;34:480-4.

22 Willcox N, Demaine AG, Newsom-Davis J, Welsh KI, Robb SA, Spiro SG. Increased frequency of IgG heavy chain marker G1m (2) and of HLA-B8 in Lambert Eaton myasthenic syndrome with and without associated lung carcinoma. Hum Immunol 1985;14:29-36.

23 Roberts A, Perera S, Lang B, Vincent A, Newsom-Davis J. Paraneoplastic myasthenic syndrome IgG inhibits Ca flux in a human small cell carcinoma line. Nature 1985;317:737-9. 